\author{
Aleksandra Geller \\ Institute of Polish Culture \\ University of Warsaw
}

\title{
"Di Ufgabn Fun Yidishizm". Debates on Modern Yiddish Culture in Interwar Poland
}

Kolegn un fraynd!

Do redt tsu aykh a birger funm land yidish. A land, on kazermes, on militer - a land, in velkhn der eyntsiker vofn iz di pen.

Ir vet dos land nisht gefinen af keyn shum veltkarte. Di grenetsn fun dem dozikn land gefinen zikh bloyz in di reyonen fun kultur-laystungen un mifuler, kinstlerisher arbet.

Der birger funm land yidish iz der birger fun der velt. Umetum, in ale kontinentn, zenen tseshlogn di kolonies fun dem dozikn yidish-land. ${ }^{1}$ (Shnayderman 1935: 464)

With these words the journalist and reporter Shmuel Leyb Shnayderman addressed his fellow writers at the 1935 PEN Club congress in Paris. His speech was one of the first instances where the word "Yiddishland" had been used. Now a popular term when referring to the cultural heritage of Eastern European Jewry, in the 1930s it was a word loaded with ideological meaning. It epitomized Yiddishist ideals and ideology that had been developing during previous decades. In this paper, I wish to examine a specific approach to modern secular Yiddish culture, one that manifested itself on the pages of the Warsaw weekly Literarishe Bleter.

Founded in Warsaw in 1924 by four Yiddish writers - the critic Nakhmen Mayzil, poets Peretz Markish and Meylekh Ravitsh, and the novelist Israel

\footnotetext{
1 "Friends and Colleagues,

Speaking to you is a citizen of the land of Yiddish. A land without barracks and armies - a land where the pen is the sole weapon. You will not find this land on any world map. The borders of this land are marked only by its cultural achievements and arduous, creative work. The citizen of this Yiddish-land is a citizen of the world. Its colonies are spread on every continent around the world."
} 
Joshua Singer - Literarishe Bleter became one of the most important, if not the most important, Yiddish literary journal of the interwar period. It was most certainly the longest lasting one. During the fifteen years of its existence, Literarishe Bleter discussed not only questions of literature, theatre and art but also more general issues of what constituted the foundations of modern Yiddish culture, what purposes it should serve and how its institutions could be strengthened. Among the journal's contributors were writers, critics, artists, actors, journalists, scholars, educators as well as cultural and political activists all deeply concerned with the challenges of building a network of Yiddish cultural institutions. Most of Literarishe Bleter's collaborators came from Poland's strongholds of Yiddish culture - Warsaw and Vilna. But even as many of them left Poland during the interwar period some continued to publish in Literarishe Bleter from their new temporary or permanent homes abroad. The journal also had a host of collaborators in other European countries as well as in North and South America, Palestine, South Africa and up to a certain point also the USSR. The pages of Literarishe Bleter were a place where all those engaged in the Yiddishist project had to cross intellectual paths. Hence the journal proves an ideal ground for exploring what it meant to be a Yiddishist in interwar Poland.

When Literarishe Bleter began its publication in the early 1920s the Yiddishist cultural project was already well underway. The transition of Yiddish from the despised jargon to a language of modern literature and the cornerstone of a secular national identity had already begun in the mid nineteenth century, but it was only towards the century's end that a real change of attitude among Jewish intellectuals became apparent. It was marked by the rise of Yiddish belles-lettres - by the turn of the century Mendele Moykher Sforim, Sholem-Aleichem, Itskhok Leyb Peretz became popular names, their works enjoyed by thousands of readers - and Jewish access to modern political movements, socialism and nationalism. As a result of the Revolution of 1905, the restrictions placed on Yiddish publishing and theatre by the Russian authorities were lifted. That in turn enabled the establishment of cultural institutions such as a mass-circulation Yiddish press, Yiddish publishing houses, libraries, reading rooms and theatres. The decade leading up to the First World War saw the explosion of a Yiddish popular culture among the Jews of the Russian Pale of Settlement especially in cities with sizeable Jewish communities such as Warsaw, Vilna and Odessa. ${ }^{2}$ In 1908 a group of writers and intellectuals gathered in the city of Czernowitz for the first Yiddish language conference. They proclaimed Yiddish as a Jewish national language and discussed future actions aimed

2 For more on the Yiddish cultural project before the First World War see: Dubnov 1929; Fishman 2005: 3-79; Trachtenberg 2008; Harshav 1990; Goldsmith 1987. 
at standardizing the language and establishing a network of cultural institutions thereby laying the foundations of the Yiddishist movement. ${ }^{3}$ During the tumultuous years of the First World War and the Russian Revolution, Yiddishists distinctly set themselves apart from the Hebraist movement, albeit many of them supported the Zionist project to varying degrees. With their own fledging school system, umbrella organizations like the Kultur-lige and much to boast of in terms of avant-garde literature, in the eyes of its activists, the Yiddishist movement of the early 1920s was growing and full of promise. ${ }^{4}$

When in 1924 Nakhmen Mayzil and his writer friends decided to launch a literary weekly, debates about the Yiddish cultural project had been going on for over two decades. Still at the core of almost every discussion, whether on matters of literature, education or theatre, remained the question of the role of Yiddish and Yiddish culture in the formation of a Jewish national identity. What were the goals of Yiddishism? How Jewish should Yiddish culture be? Should it simply be a culture in Yiddish or should it incorporate elements of the Jewish religious heritage? If so, which ones? Who exactly were the socalled "Jewish masses" so often referred to as the target readership/audience of the modern Yiddish cultural endeavours? These and other, more practical, issues surfaced time and again in the Literarishe Bleter. They were, of course, never fully resolved and yet examining the search for answers reveals the complexity of striving towards cultural autonomy in interwar Poland.

The first to directly confront Literarishe Bleter's readers with the question of Yiddishism was Khayim Shloyme Kazdan. In November 1924 the journal published his article "Yidishizm" [Yiddishism] in which the wellknown educator and later director of TSYSHO [Central Yiddish School Organization] referred to the movement as follows:

Yidishizm - iz haynt nisht keyn kultur-tregeray. Dos iz der imperativ fun dem kiyem haume. Yidishizm - heyst haynt kamf far a yidish-veltlekher bildungssistem. Kamf far der onerkenung fun yidish mitsad der melukhe, foderung fun kultur-natsyonaler oytonomye. Fun fuler glaykhbarekhtigung. Vorem mir lebn in a tsayt fun natsyonaler kristalizatsye. Di shprakh iz der oysgangs-punkt fun ot der zelbstderkenung. [...] In unzer lage iz shprakh der eyntsiker oyserlekher simen fun natsyonaler ongeherikeyt. ${ }^{5}$ (Kazdan 1924: 1).

3 For more on the Czernowitz conference see: Weiser 2010; Goldsmith 1987: 183-222.

4 See: Moss 2009.

5 “Today, Yiddishism is more than just cultural transmission [kulturtregeray], it's an imperative for the sake of national survival [kiyum ha-am]. The Yiddishism of today means fighting for a secular Yiddish school system, for the state's recognition of Yiddish, demanding a national cultural autonomy and full equality; because we live in times of national crystallization. And language is the starting point of this self-identification [zelbstderkenung]. [...] In our situation language is the only external sign of national affiliation." 
Observing the efforts of their non-Jewish neighbours at transforming an ethnic group into a modern nation, reviving a slightly faded national consciousness and/or sustaining a sense of nationhood without the help of a state apparatus, Jewish intellectuals saw that at the core of all those efforts stood the question of language - its revival, standardizing and codification in writing. If Jews wished to successfully complete the transition from an ethno-religious group to a modern nation, they too had to begin with their language. Hence Kazdan's assertion: "Yidish vert af aza oyfn ba di hayntike badingungen di frage fun ale frages. Di dozike frage ligt in unzere eygene hent"'. Jews had to catch up in the nation-building process with their Slavic neighbours and Yiddishism was the way to do it. "Yiddishism is our revolution", Kazdan exclaimed, it was the idea that would eventually lead to national and social equality for all Jews. He, therefore, called for revolutionary romanticism, idealism and unity across social and geographical divides. The rhetoric of battle was ever-present in Yiddishist discourse. There was, however, a significant shift in way the battle for Yiddish was perceived. In the early 1920s Kazdan's revolutionary fervour was an optimistic one. Knowing there was a long way ahead of him, he was fighting for a cause which he strongly believed could succeed. His enthusiasm was shared by many Yiddish writers and intellectuals of the time. Meylekh Ravitch, one of Literarishe Bleter's founders, came to Warsaw in 1921 from Vienna, this is the way he described his hopes and dreams:

Der gantser mizrekh fun Eyrope bodt zikh in flamen fun zunufgang. Di yidishe literatur vert di literatur fun gantsn yidishn folk. Yidish loshn - dos loshn fun ale yidishe tsaytn. Gor bald vet in Poyln zayn natsyonale yidishe kultur-oytonomye, un Poyln aleyn a groyse demokratishe melukhe, un di velt - a yunger gan-eydn. ${ }^{7}$ (Ravitsh 1962: 91)

As the years passed, the enthusiasm faded away, leaving Polish Yiddishists with the notion that they were no longer fighting for Yiddish but battling anti-Semitism and assimilation.

Kazdan's article, however, was still a product of the early days, it was written at a time when the issue of state subsidies for minority schools was discussed in the Polish Sejm and the Koło Żydowskie - an informal group of Jewish parliament members - failed to fight for state funding of Yiddish

\footnotetext{
6 "Given the current circumstances, Yiddish has become the most important question of all. It is all in our hands."

"All of Eastern Europe is bathed in the fiery light of the rising sun. Yiddish literature is becoming the literature of the whole nation, and Yiddish the Jewish language for all eternity. Soon Jews in Poland will enjoy a national autonomy, Poland will become a flourishing democratic state, and the world a young Garden of Eden."
} 
schools. Kazdan stressed Yiddishism's political aspect, i.e. the need to actively pursue the goal of cultural autonomy. The idea of cultural autonomy for Jews within their respective states of residence was an important part of the Yiddishist movement from the very beginning. Its most prominent advocate was the renowned historian Simon Dubnow. With his Essays on Old and New Judaism ${ }^{8}$ published in Russian from 1897 onward he created the framework of what would later be called Diaspora nationalism. Dubnow presented an evolutionary model of how nations and national consciousness changed throughout history. The primary factors binding people together were, according to Dubnow, first religion, then territory and finally culture. Jews, being a people without a territory in an ever more secularized age, had - in his view - achieved the highest form of national existence, i.e. one based on a common cultural heritage. Hence for Dubnow and his followers Zionism, with its focus on territory and statehood, was the opposite of progress. Given the circumstances, he argued, Jews should rather draw from the historical experience of institutional autonomy during the time of the First Polish Commonwealth and concentrate on strengthening their communal and cultural institutions in the Diaspora. ${ }^{9}$

It was, however, far easier to negotiate cultural autonomy within multinational empires such as Austria-Hungary and even Russia after 1905 than in the nation-states created after the former's collapse in 1918. Riddled with ethnic tension, each newly independent state was struggling to find a fine balance between the dominant culture - be it Polish, Lithuanian, Hungarian or other - and the rights of its minorities. As pointed out by Kazdan, Jewish politicians in the Polish parliament were generally unwilling to take up the issue of any form of cultural autonomy, especially when it came to Yiddish which was still regarded by many, Jews and non-Jews, as a lesser language. The notable exception was Noyekh Pryłucki, the leader of the Folkspartey and its only member to be elected to the Sejm in 1919 and 1922. Alas, his relentless campaigning for Jewish national rights won him little more than the hostility of the two other Jewish parliamentary fractions, the Zionists and the orthodox, as well as the Polish right wing parties. ${ }^{10}$ Raising Yiddishism to the highest political level proved difficult in Poland, where the government, despite official recognition of minority rights, was reluctant to support any kind of cultural autonomy seeing schools, libraries and other cultural institutions as mere steppingstones towards further territorial demands on part of the Ukrainians, Belorussians and Germans

\footnotetext{
8 For English edition see: Dubnow 1956.

9 For more on Dubnow's concept of autonomism see: Dubnov-Erlich 1991; Weinberg 1996; Brenner 2010: 93-106.

10 For more on Pryłucki see: Weiser 2011.
} 
residing within Poland's borders. The same can be said for governments of other newly independent states of East Central Europe. ${ }^{11}$ Nevertheless, the question of state funding for Yiddish institutions in Poland (or rather the discriminatory lack of it) remained a recurrent theme whenever the issue of schools, libraries or publishing was raised in Literarishe Bleter.

More worrying for Kazdan than the lack of sympathy for Yiddishism on the part of the Jewish parliament members was the reluctance of Jewish socialist parties to embrace Yiddishism as their primary ideology. Without their support Yiddishism had no chance of becoming a mass movement. Kazdan explained this reluctance by saying that proletarian parties "zey viln nisht makhn fun im [Yiddish] a fetish. Zey geyt der iker vegn inhalt funem yidishizm, un azelkher iz faran eyner bam proletariat, a tsveyter bam kleynbirgertum. Zey hobn bikhlal hekhere lozungen, "yidishizm" iz ba zey a tsveytrangike ufgabe" ${ }^{12}$. Kazdan touched on two key points that divided the supporters of Yiddish into opposing and at times even outright hostile camps. The first concerned the primary purpose of engaging in the Yiddish cultural project, the second the people to whom these efforts were addressed.

It must be stressed that not all supporters of the Yiddish language were at the same time Yiddishists in the strict sense of the term, many of them would definitely not describe themselves as such. In fact, as Avrom Golomb, also an educator involved in the Yiddish secular school movement, put it, in certain circles "men ken kalye makhn zikh di reputatsye mit azoyne zakh vi yidishizm"13 (Golomb 1928: 683). Indeed, during the interwar period the Jewish Labour Bund as well as communist fellow travellers, following the example set by Moscow, used the term Yiddishism in an increasingly derogatory fashion. This was a result of a crucial difference in the way the fundamental nature of the Yiddish cultural project was perceived. For most leftists engaged in political activity, Yiddish was considered mainly a vehicle for transmitting their ideology to a Jewish mass readership. Although Bundists and communists disagreed on several other principle matters, they shared the notion that Yiddish was a means to an end, not an end in itself. ${ }^{14}$ The very opposite was true of Yiddishists like Literarishe Bleter's editor-in-

\footnotetext{
11 For more on minority rights in the Second Polish Republic in general and Jewish rights in particular see: Tomaszewski 1985; Tomaszewski 1994: 115-127; Mendelsohn 1987.

12 "They have a somewhat narrow view of Yiddishism; they don't want to turn it into a fetish. They're more interested in the content of Yiddishism and that is a different one for the proletariat and the petit-bourgeoisie. They are generally concerned with more important things, for them Yiddishism is of secondary importance."

13 "You can ruin your reputation with such a thing as Yiddishism."

14 For more on the changing communist attitude toward Yiddish see: Estraikh 2005; Shneer 2004. On the Bundist turn from Russian to Yiddish see: Frankel 1981: 200-202.
} 
chief Nakhmen Mayzil for whom strengthening the position of Yiddish was the primary goal. In other words, the very existence of a Yiddish culture and its institutions was far more important than the political agenda behind it.

In January 1929 Literarishe Bleter published excerpts from Kalman Marmor's article summarizing a debate that had taken place in New York a month earlier; the debating parties were Dr. Chaim Zhitlovski, one of the most prominent theoreticians of Yiddishism, and Moyshe Olgin, a Bundist turned communist and editor of the communist New York newspaper Frayhayt [Freedom]. Olgin argued that a single culture could not fulfil the needs of two so different classes - the proletariat and the bourgeoisie. In his view, class struggle trumped any national affiliations one might have (or rather have had) and therefore Yiddish served as a means of creating a proletarian culture for the Jewish labourer. Although Zhitlovski was rather vague in his speech, avoiding straightforward statements, Marmor, a writer, historian and himself a communist educator, succinctly presented his opposing stance. "[...] batrakht men di yidishe shprakh un kultur far a zelbstshtendikn tsil far zikh, azoy kon zayn an eynheytlekhe klal-yisroel kultur, vos iz gemayshaftlekh far ale klasn yidn. Aza geeynikte natsyonalyidishe kultur nemt arayn in zikh alts, vos yidn hobn geshafn in ale tsaytn un in ale lender un oykh on untersheyd fun shprakh."15 ("Tsi darf di yidishe shprakh un kultur zayn nur a mitl oder a tsil far zikh"1929:66). The argument between Olgin and Zhitlovski revealed two different identifications. For Bundists and communists it was the working class or the world-proletariat, for Yiddishists klal-Isroel, all of Israel, the Jewish nation as a whole.

It's easily understandable that such a fundamental difference would lead to deep ideological conflicts within the camp of Yiddish supporters. Another aspect of the same divide was a question all those involved in supporting Yiddish cultural institutions were forced to ask themselves: who was the target of their efforts? From an ideological point of view, for Bundists and communists the answer was straightforward - their activities were directed at the proletariat. In interwar Poland, however, reality challenged ideological declarations. Apart from centres of industry like Warsaw and Łódź there wasn't much of a Jewish proletariat in the strict sense. On the other hand, the majority of the so-called Jewish masses - in large cities, and especially in the hundreds of smaller towns - were artisans, peddlers, petty traders, all of whom were not, strictly speaking, labourers. On an ideological level, however, the Bundist press - the daily Folkstsaytung and from 1931 onward the weekly Vokhnshrift far literatur kunst un teater [Weekly for literature,

15 "If you view Yiddish language and culture as an end in itself, there can exist a single unified klal-Isroel culture, one for all the Jewish classes. Such a Jewish national culture includes everything Jews have created throughout the centuries with no special regard to language." 
art and theatre] - continued to refer to di arbeter, the workmen, as Bund's main focus group. ${ }^{16}$

From that perspective, the Yiddishism of Nakhmen Mayzil and likeminded collaborators of Literarishe Bleter was branded with the allencompassing, derogatory term "reactionary" - or at best "bourgeois" - since its supporters had little regard for the dialectics of class struggle. Without the limitations of dogmatic ideology the journal presented a range of opinions. On the whole, however, the Yiddishism of Literarishe Bleter was targeted at a wider public.

Soon after the publication of his article, Chaim Shloyme Kazdan left the ranks of Literarishe Bleter's collaborators and became the journal's ideological and personal adversary, writing for the Bundist Folkstsaytung and later in Vokhnshrift. In 1924, however, Kazdan's view of Yiddishism was still inclusive. When writing about the possible target groups of the Yiddish cultural project, he mentioned not only the Jewish workman but also the artisan, the petty shopkeeper and the newly emerged Yiddishspeaking intelligentsia. Despite having pointed out the lack of ideological commitment on part of the Jewish petit-bourgeoisie, Kazdan concluded: "ober dos batayt nisht az a gantser klas darf oysgeshtrokhn vern fun der yidishistisher bavegung. Dos batayt nisht az mir darfn yidish makhn farn kinyen nur fun eyn klas. " ${ }^{17}$ This openness and the desire to provide Yiddishism with the broadest possible social basis were represented by most of Literarishe Bleter's collaborators.

Within Literarishe Bleter's intellectual circle there was a widespread belief that Yiddish culture was one of the few, if not the only, means of fighting assimilation. As noted by several cultural activists, the assimilation of the interwar period was different in kind than that of the nineteenth century. It lacked the latter's ideological programme, making it harder to fend off with debates and arguments. In 1931, the theatre critic and one of Literarishe Bleter's longstanding contributors Mikhl Vaykhert wrote: "Oyb far der milkhome hot ekzistirt a teorye fun der asimilatsye - af dem praktishn lebn fun der yidisher mase hot zi gehat a knape shlite. Hot itst di teorye bankrotirt, ober di praktishe asimilatsye iz oysgevaksn tsu a geferlekher sakone."18 (Vaykhert 1931:103). The assimilation of the interwar period was seen as a creeping process which affected mainly the younger

\footnotetext{
16 For more on Bund's activity in interwar Poland see: Jacobs 2009; Cohen 2001: 112-132.

17 "This doesn't mean that a whole class must be excluded from the Yiddishist movement and that we must turn Yiddish into the property of just one class."

18 "Before the [First World] War there existed a theory of assimilation with little practical influence on the lives of the Jewish masses. Today, that theory is bankrupt, but the practice of assimilation has become a great threat." See also: Golomb 1931: 1.
} 
generation undergoing compulsory schooling mostly in Polish-language institutions. It began with linguistic acculturation and could quickly lead to loosening ties with one's Jewishness or losing them altogether. During the 1930s more and more writers voiced their concern about the state of Polish Jewry, it seemed that despite the growing anti-Semitism of the time, linguistic and cultural Polonization continued at an alarming rate.

In that context, Chaim Zhitlovski in his article "Yidishizm un natsyonalizm" [Yiddishism and nationalism] brought up an important distinction. He discussed the difference between a national and a nationalistic movement. The former had a national form (language) but a universal content; the latter focused also on a national content. According to Zhitlovski, Bundism was, therefore, a national movement whereas Yiddishism could and should be called nationalistic, with the reservation that it was free of the chauvinism and national egoism usually associated with the term. "Der yidishizm shtrebt dertsu az dos gantse lebn un shafn fun unzer folk zol farkumen in der sfere fun dem yidishn loshn"19, wrote Zhitlovski, and concluded that "On dem natsyonalistishn grunt un yesod, vos derklert dem yidishizm far a natsyonaler lebns-noyt fun dem yidishn folk - koydem-kol; on dem groysn ideal fun der yidisher folks-bafrayung, fun der progresiv-natsyonaler vidergeburt unzerer, hot di yidishe dertsiyung - vi oykh di yidishe literatur un di gantse yidishe kultur in der yidisher shprakh - keyn brekl zin nisht." ${ }^{20}$ (Zhitlovski 1925: 1) The question underlying Zhitlovski's argument was, how Jewish should Yiddish culture be. Was the very fact of using a Jewish language enough to turn Yiddish culture into a national culture (should it be considered a national culture at all, some might add)? Could Yiddish culture cut itself off completely from its religious root? Or should it be embedded in and draw from the heritage of the traditional Jewish way of life? If so, to what extent? In their essence, these questions all boiled down to one of the most fundamental issues faced by Jews in modern times, namely, how Jewish should modernizing Jews remain and what constituted the sine qua non of a Jewish identity. The spectrum of answers was, of course, very wide.

Radical Bundists and communists advocated a proletarian culture in Yiddish with no connection to the religious tradition whatsoever. Their stance on the national question is what set them apart. ${ }^{21}$ Such radical views

\footnotetext{
19 "Yiddishism strives to ensure that all aspects of our people's lives and creative endeavours can be fulfilled in the Yiddish language."

20 "First of all, without the nationalistic foundations that declare Yiddishism to be a national necessity for the Jewish people, without the great idea of freeing the Jewish people, of a progressive, national rebirth, Jewish education as well as literature and Jewish culture in Yiddish as a whole haven't the least bit of sense."

${ }^{21}$ See: Fishman 2005: 48-61; 98-113.
} 
were rarely seen in Literarishe Bleter. An interesting but rather isolated view was that of the avant-garde poet Peretz Markish. In one of Literarishe Bleter's very first issues, he argued that Yiddish literature, and with it Yiddish culture in general, was in desperate need of a positive ideal it could embrace. Fighting "against" (the traditional way of life, mental confinements and antiquated literary forms) wasn't enough, Yiddish literature needed to be purposeful and also fight for a certain cause. In his view, given the historical experience of the Diaspora, Jews should make internationalism the new ideal at the core of their creative thinking. The Yiddish language in itself embodied the international and the interpersonal. Being a mixed language, it had unwittingly prepared Jews to embrace the international ideal. Internationalism could, therefore, become the new national ideal of the Jewish people. ${ }^{22}$ This rather bold, paradoxical line of reasoning indicated not only Markish's own revolutionary inclinations, but was also evidence of Literarishe Bleter's early rebelliousness.

By 1926, the year Markish left Poland for Soviet Russia, Mayzil's journal already presented more moderate views. ${ }^{23}$ Many of the journal's contributors followed the lead of the "father of Yiddish literature" Itskhok Leyb Peretz, in that they saw secular Yiddish culture as a transformation and continuity of Jewish folk culture rooted in the traditional way of life. ${ }^{24}$ Laying out the principles of Yiddishism, Avrom Golomb stated that "dos naye boyt zikh af dem altn un fun dem altn [...] nutst oys un shaft iber di yerushe fun ale forike tkufes"25 (Golomb 1928: 684). Indeed modern Yiddish creativity, as envisioned by Golomb, Mayzil and like-minded Yiddishists, was supposed to draw from the life of the Jewish people. Whether it be in terms of themes and topics presented in literature, theatre, paintings or sculptures or by using certain traditional Jewish literary forms - the midrash, the Chassidic tale - as means of modern literary expression. This national-romantic version of Yiddish culture rather than thinking of Jewishness as stemming directly from religion, drew it from the cultural heritage of the Jewish people. The Yiddishist project sought to transform Ashkenazi folk-culture into the cornerstone of a national culture. Hence the focus on folkloristics, ethnography and what was known as yidishe visnshaft, Yiddish scholarship. Fitting the various forms of Yiddish creative expression into the meta-

\footnotetext{
22 Markish 1924: 1, 6.

23 Writing on the anniversary of the 100th issue, the writer and photographer Alter Katsyzne called Literarishe Bleter "di zkeyne", the old woman. In the beginning, wrote Katsyzne, the journal was like a gust of wind, with time gone by it became more cautious and temperate. See: Katsyzne 1926: 215.

24 For more on Peretz's concept of Yiddish culture see: Wisse 1991; Fishman 2005: 98-113.

25 "The new is built on the old [...] [it] draws from and reshapes the heritage of all the bygone ages."
} 
structure of scientific categories and concepts - whether they be from the field of history, linguistics, sociology, art history, literary criticism or other - was an important part of creating the canon of Yiddish culture, an entity that could then be presented to the broad Yiddish-speaking public mainly through the school system and the press, and serve as the basis for their Jewish national identity. ${ }^{26}$

Moreover, if Yiddish culture was to be an effective means against assimilation, it had to provide the same cultural "goods" as the surrounding non-Jewish cultures. There had to be a modern Yiddish literature as well as translations of world literature (old and new) into Yiddish, scholarly literature, theatre, a path toward higher, secular education, etc. In other words, there was a need for a high culture in Yiddish. Only that could prevent Jews from turning to other languages and losing their intellectual ties with Yiddish. Advocating this stance was Shmuel Niger, a wellrespected literary critic and historian. ${ }^{27}$ In an article published in 1926 he tried to refute Bundist criticism by laying out the principles of Yiddishism.

Der tsil fun der yidishistisher bavegung iz geven un iz - breyter makhn di grenitsn un di horizontn fun dem yidishn shafn. [...] Di opshvakhung un di oysrotung fun der provintsyoneler bashrenktkayt fun der yidisher literatur iz geven der tifster farlang un di vikhtikste ufgabe fun yidishizm. ${ }^{28}$ (Niger 1926: 647)

Yiddishists gathered around Literarishe Bleter all supported the efforts of 'elevating' Yiddish culture, so that it could be perceived as equal to the surrounding non-Jewish national cultures, Russian, German, Polish. They sought to do so by placing it within the framework of a scientific metadiscourse, creating a network of cultural institutions and making all of European culture available to Yiddish-speakers through Yiddish.

Nakhmen Mayzil himself saw Literarishe Bleter as a means of disseminating both Yiddish high culture and high culture in Yiddish. Throughout its existence the journal had a somewhat didactic trait. It regularly published articles on certain trends or themes in Jewish and European literature, theatre, art and sometimes even music; it also featured biographical pieces on Jewish and non-Jewish writers and artists as well as interviews with both Polish writers, actors and artists and those visiting Poland from abroad. In accordance with the Yiddishist agenda, Literarishe Bleter wanted, first,

\footnotetext{
26 For more on Yiddish folklorists see: Gottesman 2003; Weiser 2011; Safran 2010: 186-205; on Yiddish scholarship see: Trachtenberg 2008: 46-81.

27 For more on Niger's Yiddishism see: Trachtenberg 2008: 82-134.

28 "The goal of the Yiddishist movement was - and still is - to expand the boundaries and horizons of Yiddish creativity. [...] Weakening and dismantling the provincial constraints of Yiddish literature has always been Yiddishism's deepest desire and most important task."
} 
to help its readers further their knowledge of Jewish literature and art history - many of them had little or no formal secular education at all and second, to give them access to the modern non-Jewish culture so that they would not have to resort to Polish journals and books. And indeed it seems that on a theoretical level Mayzil's journal served those purposes well, bringing Yiddish scholarship and literature as well as figures like Thomas Mann, Romain Rolland, Panait Istrati and Rabindranath Tagore to over two hundred and twenty cities and towns across Poland and over eighty cities abroad. In practice, however, these efforts could not stop the ongoing process of acculturation. ${ }^{29}$

Apart from its educational agenda, Literarishe Bleter also sought to facilitate the communication between different centres of Yiddish culture around the world. Geographical dispersion was indeed an important feature of Yiddish culture. The so-called Yiddishland was in fact an imagined (but not in the least imaginary) country without borders that could materialize in any place Yiddish-speaking Jews chose to settle, whether it be Warsaw, New York, Buenos Aires, Johannesburg or Sydney. This state of dispersion became the subject of increased debates during the interwar period. Since every land had its capital, Yiddishists were also searching for the "centre of Yiddish culture", a place that would radiate creative energy and set the dominant agenda for Yiddishists around the world. The three main contenders in that race were Warsaw, Moscow and New York, each city representing a somewhat different vision of what Yiddish culture should be. Broadly speaking, New York and Moscow represented the leap into the modern world in its two incarnations - the culture of the capitalist metropolis and the communist utopia. Warsaw on the other hand, and Poland in general, stood for continuity. For some it was a positive continuity, the kind that incorporated the past, transformed and modernized it, thus creating a culture accessible and appealing to the changing Jewish community. For others, notably Soviet communists, it was perceived rather as stagnation and clinging to antiquated forms of creativity and ways of thinking. ${ }^{30}$ Over the course of two decades, the question of the centre of Yiddish culture surfaced in Literarishe Bleter time and again. ${ }^{31}$ There was, of course, never a consensus as to which centre was indeed the dominant one. The very fact that there was a need to search for such a centre proves the deeply-rooted need for unity and unification among Yiddishists worldwide.

\footnotetext{
29 See for example: Cohen 2011.

30 See: Bergelson 1926: 84-96. For English translation see: Sherman et al 2007: 347-355.

31 See for example: Mayzil 1925: 262-264; Ravitsh 1926: 694-696, 709-711, 745-747, 822-823; Mestel 1926: 85-86; Molodovsky 1933: 693-694.
} 
The educator Avrom Golomb approached the question of dispersion from an interesting vantage point. In 1926, analysing the current conditions in which Yiddish culture was developing, he wrote:

Di hayntike ekonomishe faktorn un komunikatsye-mitlen zorgn shoyn genug far dem, az natsyes un felker zoln zikh oysmishn, az keyn etnografish rayne teritoryes zoln nisht zayn. Di bagrifn melukhe un natsye hobn zikh gedekt nor in fargangenheyt. Haynt tsu tog iz shoyn zeltn tsu gefinen an eynheytlekh bafelkerte melukhe oder a natsye vos zol ingantsn kontsentrirt zayn in ir melukhe. Un dos iz nor di hatkhole. In tokh arayn zenen "melukhe" un "natsye" tsvey bagrifn, vos kreytsn zikh nor un mer nisht. ${ }^{32}$ (Golomb 1926: 586)

Having the benefit of hindsight we see that Golomb's prognosis proved true to a very high degree. In the 1920s, however, the notion that every nation had its Diaspora and every country its minorities wasn't very popular. The recognition that nation-states were in most cases multinational went against the dominant nationalistic rhetoric of the day. For Golomb, Yiddishism, which substituted religious and/or territorial unity with a linguistic and cultural one, was the best possible way of adapting to the changing world. It created a framework for a secular Jewish collective identity while remaining open to non-Jewish cultures and flexible in adapting to political and social changes. Golomb's argument was in some aspects similar to that of Peretz Markish. Both acknowledged that due to their historical experience Jews were ahead of their time, they were the avant-garde of the modern world and their example could serve as a model for other nations to follow.

On a practical level, the dispersion of Yiddish culture posed several practical problems. Yiddish-speaking communities in different states lived in different political, socio-economic, cultural realities. They were surrounded by different languages, operated under different legal systems, had a different degree of political influence. All this contributed to the feeling that various parts of the Yiddishland were growing further and further apart. Literarishe Bleter could, of course, do little to influence these external factors. Mayzil's goal, however, was to create a forum for Yiddishists to engage in discussions and freely exchange ideas regardless of their political views and place of residence.

In an article commemorating the 100th issue of Literarishe Bleter, Mayzil wrote: "zenen di Bleter mit der tsayt gevorn a min kibets-golyes far

\footnotetext{
32 "Current economic factors and ways of communication are already ensuring that nations and peoples are mingling, that there will no longer be any ethnically homogenous territories. The terms "nation" and "state" were congruent only in the past. Today, it is difficult to find a state with a homogenous population or a nation living only within the borders of its state. And this is just the beginning. In essence, "state" and "nation" are terms that overlap and nothing more."
} 
farsheydnartikste yidshe kultur-shafer fun gor der velt. [...] a min heym farn yidishn heymlozn shrayber "33 (Mayzil 1926: 325). He also refuted criticism directed at the journal for lacking a defined programme. The lack of a manifesto in Literarishe Bleter's first issue was in his opinion an advantage rather than a drawback, since it opened the journal to all writers and cultural activists regardless of their aesthetic and/or political affiliations. Mayzil concluded as follows:

[di Bleter] bamien zikh tsu dernentern di 'kemfndike' koykhes, zey viln farvishn frontn un aroysgefinen gemeynzame interesn, gemeynzame viln un shtrebn tsu farshtarkn unzer yung un dervayl nokh genug shvakh kultur-organizm, vu er zol nisht ufkumen - in rusland oder amerike, in poyln oder argentine. [...] keynmol zenen ba eyn tish, in eyn literarishn getselt nisht baygeven azelkhe farsheydnartike dikhter vi in di Bleter "34 (Mayzil 1926: 326).

This kind of narrative was present throughout the fifteen-year period of the journal's existence. Statements about how it connected Yiddish writers and readers from around the world were repeated time and again in anniversary articles. Celebrating the $300^{\text {th }}$ issue, the Vilna Yiddishist Moyshe Shalit wrote that the journal was like "a kegnzaytiker shtrom, vos brengt varemkayt un gemeynshaft un dernentert di boyer un tuer fun ale merakim. Un azoy hobn di Literarishe Bleter geshafn mit zeyer eytsem egzistents a shtikl emesdikn, pulsirndikn tsenter" 35 (Shalit 1930: 80). Ten years later, in October 1938, celebrating the $750^{\text {th }}$ issue, the Lithuanian communal leader Mendel Sudarsky wrote: "Di 'Lit. Bleter' zenen, mit eyn vort, gevorn der tsentral-nerv, vos farbindt unz mit dem gaystikn shafn, kultureln lebn fun unzer folk in zayn gantser tseshpreytkayt." ${ }^{36}$ (Sudarsky 1938: 651) Mayzil's own description, as well as those of the journal's supporters, were somewhat utopian, Literarishe Bleter did, of course, have its opponents. In Warsaw only, there was the Bundist Folkstsaytung, the communist Literarishe Tribune, as well as the more right-wing monthly Globus. Some authors took to ridiculing

\footnotetext{
33 "With time Literarishe Bleter became a gathering place for various Yiddish cultural creators from around the world. [...] a kind of home for the homeless Yiddish writer."

34 "[Literarishe Bleter] try hard to bring together the "fighting" forces; they wish to dismantle frontlines and discover mutual interests, a common will and resolve - to strengthen our young and still quite fragile cultural structure wherever it should spring up - in Russia or America, in Poland or Argentina. Never before have so different poets sat together at one table, under one literary roof, as in Literarishe Bleter."

35 "A two-way current bringing warmth and community that unites activists from every corner. By means of their sheer existence, Literarishe Bleter have managed to create a really vibrant centre." 36 "In short, Literarishe Bleter have become the central nerve that links us with the spiritual creativity and the cultural life of our people in all its dispersion."
} 
Mayzil's naiveté ${ }^{37}$, others launched fierce ideological and personal attacks on the journal and its editor ${ }^{38}$. Still, it should be stressed that Mayzil managed to achieve what no other journal of the interwar period had: he was able to secure the collaboration of people with different political and aesthetic views as well as battle financial difficulties and establish Literarishe Bleter's firm presence among Yiddish press titles.

Reflections on Yiddishism and its role in creating a national movement within the Jewish Diaspora inevitably raised the question of the Yiddishists' attitude towards Zionism and the Hebraists. As with socialism and communism, Literarishe Bleter presented an equally wide range of opinions about the Hebrew language revival, as well as the nature and the usefulness of Zionist ideology. Among the journal's collaborators were writers, scholars and activists connected with the Left Poalei Tsiyon, a Zionist movement dedicated nevertheless to promoting Yiddish language and culture. Many of Literarishe Bleter's contributors, however, shared the notion - in line with Dubnow's thinking - that while Yiddishism was the final step in the evolution of the Jewish national conscience, political Zionism was simply an attempt to create a Jewish version of an essentially non-Jewish concept, i.e. territorial nationalism. In that sense, Yiddishism was perceived as an authentically Jewish ideology whereas Zionism was often lumped together with the Haskala and portrayed as an idea foreign to the Jewish way of thinking. ${ }^{39}$ These statements were, of course, oversimplifications. Neither was Yiddishism a "natural" consequence of the Jewish historical experience, nor were Zionism and Hebraism elitist ideas with no resonance among the Jewish people. Nevertheless, this narrative adopted by many Yiddishists served to pit supporters of one Jewish language against the supporters of the other.

During the 1930s the unfolding events in Germany, the general rise of anti-Semitism in Europe, the purges in the Soviet Union, as well as the world-wide economic crisis cast a dark shadow over the Yiddishist project. In 1937 an international group of Yiddishist, Nakhmen Mayzil among them, tried to spur enthusiasm for Yiddishism by organizing a Yiddish cultural congress in Paris. Despite these efforts, the general mood was sinking. The Paris congress only exposed the fierce internecine conflicts. Ideological differences among the supporters of Yiddish were larger than ever and linguistic assimilation both in Poland and America gave cause for grave concern. This tension and feelings of unease were poignantly

37 See: B. [Bashevis] 1932: 85-87.

38 See for example: Rapaport 1931.

39 See for example: Golomb 1926: 562-564; Tseytlin 1931: 857-858, 874-876. 
summed up by the poet and critic Shmuel Zaromb in an article entitled "On a breyre" [Without choice] published in Literarishe Bleter in December 1938. In light of the tragic plight of German Jewry (the article was written shortly after the Kristallnacht), the author reevaluated the achievements of the project of a secular Jewish culture in general. He wanted to understand, what influence the secularization of Jewish culture had on the Jews' ability to face the situation when their rights and their place in modern Europe were fundamentally questioned. Zaromb asked: "vos fara naye vertn hobn mir bashafn, vos far an alte vertn hobn mir ufgehitn un nisht farlendt in unz, vos zol unz gebn di ibertseygung in der noytvendikayt fun unzere yesurim?" ${ }^{40}$ (Zaromb 1938: 766). Zaromb argued that within a religious worldview Jewish suffering could be perceived as part of God's plan and thus become meaningful. This notion brought comfort to the persecuted and helped them endure their pain with dignity. In a secular framework, however, Jews had lost their status as the chosen people. They had become a nation like any other, their history no longer determined by God but by abstract forces whose teleological meaning was impossible to grasp. Today, Zaromb concluded, Jews stood aghast when trying to make sense of their tragic plight. With this line of reasoning, Zaromb implicitly questioned the whole philosophy of the Jewish Enlightenment and all the modernization projects that followed. He was not alone in his disillusionment. From 1933 onward the intellectual crisis among Yiddishists deepened with every passing year. During that time tens of writers, artists, actors and cultural activists left Poland, the heart of the Yiddishland, seeking refuge in one of its "colonies". By 1939 all four of Literarishe Bleter's "founding fathers" had long left Poland never to return.

\section{References}

B. [Bashevis]

(1932) "20 teg, vos hobn ufgetreyselt di velt oder di gilgulim fun a yingen dikhter", Globus, no. 1, pp. 85-87.

Bergelson D.

(1926) "Dray tsentern", In shpan, no. 1, pp. 84-96.

Brenner M.

(2010) Prophets of the Past. Interpreters of Jewish History, Princeton.

Cohen N.

(2001) "The Bund's Contribution to Yiddish Culture in Poland", [in:] J.L. Jacobs (ed.), Jewish Politics in Eastern Europe: Bund at 100, New York, pp. 112-132.

(2011) „Czytelnictwo książek polskich w żydowskich bibliotekach w okresie

\footnotetext{
40 "What new values have we created, what old values have we preserved and not destroyed that could convince us of the necessity of our suffering."
} 
międzywojennym”, [in:] E. Prokop-Janiec, S. Żurek (eds.), Literatura polskożydowska. Studia i szkice, Kraków, pp. 21-26.

Dubnow S.

(1956) Nationalism and History. Essays on Old and New Judaism, Philadelphia.

Dubnov Sh.

(1929) Fun "zhargon" tsu yidish un andere artiklen, literarishe zikhroynes, Varshe.

Dubnov-Erlich S.

(1991) The Life and Work of S.M. Dubnov: Diaspora Nationalism and Jewish History, Bloomington.

Estraikh G.

(2005) In Harness. Yiddish Writers' Romance with Communism, Syracuse.

Fishman D.E.

(2005) The Rise of Modern Yiddish Culture, Pittsburgh.

Frankel J.

(1981) Prophecy and Politics: Socialism, Nationalism and the Russian Jews 1862-1917, Cambridge.

Goldsmith E.

(1987) Modern Yiddish Culture: The Story of the Modern Yiddish Language Movement, New York.

Golomb A.

(1926) "Alveltlekhe yidishkayt", Literarishe Bleter, no. 121, 122, pp. 562-564, 585-586.

(1928) “Di ufgabn fun yidishizm” Literarishe Bleter, no. 35, 37, pp. 683-684, 726-727.

(1931) “Es yogt a kulturlozikeyt”, Vokhnszrift, no. 24, p. 1.

Gottesman I.N.

(2003) Defining the Yiddish Nation: The Jewish Folklorists of Poland, Detroit.

Harshav B.

(1990) The Meaning of Yiddish, Berkeley.

Jacobs J.L.

(2009) Bundist Counterculture in Interwar Poland, Syracuse.

Katsyzne A.

(1926) “Di zkeyne. Tsum hundertstn numer”, Literarishe Bleter, no. 99-100, p. 215.

Kazdan K.Sh.

(1924) “Yidishizm”, Literarishe Bleter, no. 29, p. 1.

Markish P.

(1924) "On an idey", Literarishe Bleter, no. 3, p. 1, 6.

Mayzil N.

(1925) "Varshe, Nyu York, Moskve. Arum dem kamf vegn der hegemonye iber der yidisher literatur", Literarishe Bleter, no. 82, p. 262-264.

(1926) “Etlekhe verter vegn di ,Lit. Bleter”, Literarishe Bleter, no. 107, pp. 325-327.

Mendelsohn E.

(1987) The Jews of East Central Europe Between the World Wars, Bloomington.

Mestel Y.

(1926) “Bimkom an ufruf”, Literarishe Bleter, no. 92, pp. 85-86. 
Molodovsky K.

(1933) “Di mode tsu 'farnaynen’ Varshe”, Literarishe Bleter, no. 44, pp. 693-694.

Moss K.

(2009) Jewish Renaissance in the Russian Revolution, Cambridge.

Niger Sh.

(1926) “Vos iz yidishizm”, Literarishe Bleter, no. 125, 126, pp. 627-629, 647-648.

Rapaport J.

(1931) Literarishe Bleter. Zeyer redaktor un unzere literarishe svive, Varshe.

Ravitsh M.

(1926) “Arum velkher aks dreyt zikh di yidishe literatur",Literarishe Bleter, no. 129, 130, 132, 136, pp. 694-696, 709-711, 745-747, 822-823.

(1962) Dos mayse-bukh fun mayn lebn, vol. 3, Buenos Aires.

Safran G.

(2010) Wandering Soul. The Dybbuk's Creator S. An-sky, Cambridge, MA.

Shalit M.

(1930) “300 numern literatur”, Literarishe Bleter, no. 5, pp. 79-80.

Shnayderman Sh.L.

(1935) "Di antifashistishe tendentsn in der yidisher literatur", Literarishe Bleter, no. 29, p. 464.

Sherman J., Estraikh G. (eds.)

(2007) David Bergelson. From Modernism to Socialism, London.

Shneer D.

(2004) Yiddish and the Creation of Soviet Jewish Culture, 1918-1930, Cambridge.

Sudarsky M.

(1930) "Der koyekh fun libe un ekshones", Literarishe Bleter, no. 39-40, p. 651.

Tomaszewski J.

(1985) Rzeczpospolita wielu narodów, Warszawa.

(1994) “The Civil Rights of Jews in Poland, 1918-1939”, Polin 8, pp. 115-127.

Trachtenberg B.

(2008) The Revolutionary Roots of Modern Yiddish 1903-1917, New York.

Tseytlin A.

(1931) “An ofener briv tsu Khayim Nakhmen Bialik”, Literarishe Bleter, no. 46, 47, pp. 857-858, 874-876.

“Tsi darf di yidishe shprakh un kultur zayn nur a mitl oder a tsil far zikh"

(1929) Literarishe Bleter, no. 4, pp. 66-67.

Weinberg D.H.

(1996) Between Tradition and Modernity: Haim Zhitlovsky, Simon Dubnov, Ahad Ha'am, and the Shaping of Modern Jewish Identity, New York.

Weiser K., Fogel J.A. (eds.)

(2010) Czernowitz at 100. The First Yiddish Language Conference in Historical Perspective, Plymouth.

Weiser K.

(2011) Jewish People, Yiddish Nation. Noah Prylucki and the Folkists in Poland, Toronto. 
Wisse R.

(1991) I. L. Peretz and the Making of Modern Jewish Culture, Seattle.

Vaykhert M.

(1931) “Di misye fun yidishn shrayber”, Literarisze Bleter, no. 6, pp. 102-103.

Zaromb Sh.

(1938) “On a breyre", Literarishe Bleter, no. 48/49, pp. 765-766.

Zhitlovski Ch.

(1925) "Yidishizm un natsyonalizm", Literarisze Bleter, no. 42, pp. 1-2.

\section{Czym jest jidyszyzm? \\ Debaty o nowoczesnej kulturze jidysz w międzywojennej Polsce}

Jidyszyzm, czyli projekt budowania nowoczesnej tożsamości narodowej w oparciu o kulturę jidysz, rozkwitł najpełniej w latach dwudziestych XX wieku. W tym okresie Polska była jednym z najważniejszych, o ile nie najważniejszym ośrodkiem ruchu jidyszystycznego. To tutaj rozwijała się literatura jidysz, prasa, teatr, nauka oraz szkolnictwo w tym języku. Niniejszy artykuł przedstawia podstawowe teoretyczne założenia jidyszyzmu oraz pytania, z którymi musieli zmierzyć się jego zwolennicy. Jak żydowska winna być kultura jidysz? Czy wystarczy, by była kulturą w jidysz, czy też powinna opierać się na elementach tradycji religijnej, a jeśli tak, to jakich? O kim myślano, pisząc o tzw. „masach żydowskich”, odbiorcach kultury jidysz? Czy mimo geograficznego rozproszenia mówców jidysz na pięciu kontynentach możliwe było stworzenie jednej spójnej, ponadpaństwowej kultury narodowej? Przedstawione w tym artykule rozważania międzywojennych jidyszystów pochodzą przede wszystkim z tygodnika Literarisze Bleter, jidyszowego czasopisma literackiego założonego w Warszawie w 1924 roku przez grupę młodych pisarzy. Tygodnik ten był najdłużej wychodzącym jidyszowym czasopismem literackim w okresie międzywojennym, z czasem stał się też jednym z najbardziej opiniotwórczych periodyków. Na jego łamach spotykali się wszyscy pisarze, publicyści, działacze społeczni zaangażowani w rozwój języka oraz instytucji kultury jidysz - jedni w roli współpracowników, inni adwersarzy. Współczesnemu czytelnikowi i badaczowi polemiki z Literarisze Bleter odsłaniają teoretyczne i praktyczne problemy, z którymi musieli mierzyć się zwolennicy żydowskiej autonomii kulturalnej w międzywojennej Polsce. 


\section{What Is Yiddishism? \\ Debates on Modern Yiddish Culture in the Interwar Poland}

Modern secular Yiddish culture reached the peak of its development during the 1920s and Poland was at that time one of the main centres where Yiddish literature, theatre, press, scholarship and schools flourished. This paper outlines the basic principles of Yiddishism, a Diaspora-based national movement that saw language and culture as the cornerstones of a secular Jewish identity. It also presents some of the major theoretical questions faced by its supporters. What were the goals of Yiddishism? How Jewish should Yiddish culture be? Should it simply be a culture in Yiddish or should it incorporate elements of the Jewish religious heritage? If so, which ones? Who exactly were the so-called "Jewish masses" so often referred to as the target readership/audience of the modern Yiddish cultural project? How could the challenges of geographical dispersion be overcome? The arguments presented in this paper are based mostly on material found in the weekly Literarishe Bleter, where these and other questions surfaced time and again. Founded in Warsaw in 1924 by a group of Yiddish writers, it was the longest lasting and probably the most influential Yiddish literary journal of the its time. Throughout the interwar period it was a place where all supporters of the Yiddish language movement crossed intellectual paths, either as collaborators or adversaries. Today, Literarishe Bleter enable its modern reader to see the complexity of what it meant to strive towards cultural autonomy in interwar Poland.

Key words: Yiddishism, Yiddish culture, Yiddishland, Yiddish press, interwar Poland, Literarishe Bleter, Nakhmen Mayzil, Avrom Golomb 